\title{
COOPERATIVES' MARKET ACTIVITIES IN THE SPHERE OF SALES MARKETING. COMPARATIVE ANALYSIS ON THE EXAMPLE OF DAIRY COOPERATIVES FROM THE MALOPOLSKIE AND ŚWIĘTOKRZYSKIE VOIVODSHIPS
}

\author{
Izabela KONIECZNA \\ The Jan Kochanowski University in Kielce, Faculty of Law and Social Sciences, Department of Management; \\ irud@interia.pl, ORCID: 0000-0002-3632-3245
}

Purpose: The aim of the article is to identify activities creating value for the customer in the area of sales marketing and to compare them between the two neighboring voivodships, namely Świętokrzyskie and Małopolskie.

Design/methodology/approach: Direct interviews using a questionnaire survey were conducted among representatives of cooperatives representing $41 \%$ of the population, which resulted from the willingness to participate in the survey.

Findings: The analysis of the research results, taking into account two voivodships shows that although sales marketing activities have an impact on customer value, most of them are not carried out by all cooperatives. Moreover, in the case of other major markets, no action is taken. In most cases, the voivodship in which the cooperatives operate differentiates the undertaken activities.

Research limitations/implications: A limitation of the research is the range. It results from the fact that only cooperatives from two voivodships, namely Świętokrzyskie and Małopolskie were researched here. In addition, the research results are limited to one organizational and legal form of enterprises, i.e. cooperatives. It seems reasonable that further research should be at least nationwide and cover various organizational and legal forms of enterprises.

Practical implications: Analysis of the results allows enterprises' management to be more aware of the need of analyzing activities in the field of marketing sales more often, as it affects the value to the customer. Such awareness allows them to take appropriate steps to increase the scope of taken actions, and thus affect the value for the customer to a greater extent than the competition.

Originality/value: The comparison of market activities in the sphere of sales marketing of selected cooperatives from two different voivodships.

Keywords: customer value, market activities, sales marketing, cooperatives.

Category of the paper: Research paper. 


\section{Introduction}

Marketing is a contemporary concept of human behavior in many areas of life. It can be considered from various points of view: all producers and consumers operating in a given economy (this is so-called macromarketing, important in the aspect of the functioning of nonprofit organizations, understood as a social process) and the single producer and buyers of its products or services (this is so-called micromarketing, i.e. a management process that is a deliberate way of proceeding in the market, based on an integrated set of instruments and activities as well as market orientation, the purpose of which is to ensure the success of organizations) (Limański, 2007, pp. 50-51). Marketing activity in the field of micromarketing is the conduct of business entities and other organizations based on certain rules. It aims to understand and adapt to the market as well as influence on the demand and supply, taking into account the needs, requirements and preferences of final recipients, as well as the social and microeconomic point of view. By observing the mutually beneficial exchange and taking into account the postulates of the master plan, a given economic entity formulates a procedure program, then applies it and checks its implementation (Garbarski, 2011, p. 18).

Marketing and market orientation is the basic premise of business management. This allows to formulate the concept of strategic functioning of marketing in such organizational unit. Marketing activity is developed on the basis of the mission for which the company exists and on the basis of strategic goals (Durlik, 1995, pp. 265-266). Marketing is the process of researching a product in relation to the market, it is determining how to maximize the potential of a product in a given market. Careful and thoughtful marketing can help in finding the best sector of the market in which the company can be successful against the competition, and define the function that the product should fulfill. (Sampson, 1996, p. 51). Enterprises, through their activities involving sales marketing, strive to maximize value for the customer and the enterprise itself. In the case of the customer, this is to meet his expectations as much as possible. In contrast, partial objectives of marketing targeted on the value of the company are: (1) gaining and maintaining a high market position, reflected in the appropriate image and reputation of the company as well as in the market share, (2) shaping mutually beneficial partnerships with customers, (3) systematic expansion of the group of regular and loyal buyers, (4) strengthening the impact and effectiveness of the marketing tools held: product, assortment program, price instruments, distribution system and promotional assets (Niestrój, 2002, p. 176).

Marketing and sales consist of activities that deal with the analysis of markets and consumers, influencing the customer to make a purchase, and ensuring product availability through appropriate channels (Stonehouse, Hamill, Campbell, Purdie, 2001, p. 42). Marketing is the sum of certain very diverse activities related to the development of the product concept, the principles of pricing, forms of sale and forms of promotion of the company's products. In order to take effective action in each of these areas, the company needs information about 
the market, i.e. knowledge about the behavior of buyers, about competitors. (Domański, 1994, p. 14) and own organization. At this point, the preparatory functions of marketing are indispensable, i.e. gathering market information; market research; product and assortment program planning; calculation and pricing; organizing a distribution system; planning promotional activities; control and analysis of marketing results (Czubała, 2012, pp. 289-290). The type of data at the company's disposal has a significant impact on shaping marketing strategies and, consequently, on gaining a competitive advantage and business development. The scope and features of the information obtained depend on the type of business activity, the functioning of a given industry and sector of the economy (Pieczykolan, 2005, p. 65). This is where the executive functions of marketing are used (advertising; sales activation; direct customer service: information, negotiations, contracting, sales, rental, complaints, etc.; freight forwarding; transport and forwarding; stock management of finished products/goods; customer service; invoicing and contract performance control) and supporting functions (financing: distributor crediting, installment sales, leasing, etc.; risk participation and insurance against its consequences) (Czubała, 2012, pp. 289-290).

Marketing is the focus on the customer that covers all the functions and processes of the organization, aimed at making promises in the form of value propositions, enabling the fulfillment of individual expectations resulting from these promises by supporting customers in the process of creating value and thus contributing to creating value in the processes undertaken in the company by its customers and other stakeholders (Garbarski, 2011, p. 20). A modern approach to marketing requires identifying and acquiring the most profitable customers - key for the company, and then appropriate management of relationships with them (Grzanka, 2009, p. 18). This selected group of recipients is the so-called the target market, and in this case, marketing consists in carrying out activities consisting in a thorough knowledge of the needs of a selected group of recipients and possibly perfect adaptation of the company's offer to the expectations of this group (Domański, 1998, p. 13). This main task of marketing in a company is to define consumer preferences and meet their needs and ideas in such a way that the company makes a profit and the buyer is satisfied with the transaction. (Żurawik, 1996, p. 16). This is because it is important for increasing sales efficiency and gaining a competitive advantage (Grzanka, 2009, p. 18).

\section{Methods}

The modern market is mainly created by the demand, and therefore by the customer. He is the recipient of the company's products / services, so the company must firstly identify him quickly, define his needs and try to discover his intentions that may guide his actions. They should be converted into effective demand through appropriate marketing activities 
(Lawicki, 2005, p. 15). To achieve this, enterprises must undertake specific actions affecting the value for customers, which may include: offering products that are competitively priced, applying promotional prices, targeting end recipients, using loyalty programs, using consumer promotions (e.g. samples, coupons, contests, lotteries, gifts, etc.), use of public relations, use of publicity, wide sharing of information about the offer, offering products with a competitive warranty scope, individualizing the offer, offering products on favorable terms of payment/ financing, applying special conditions of sale (discounts), offering products with a rich set of pre-, around- and after-sales services and offering a competitive price for pre-, around- and after-sales services (Konieczna, 2015, p. 101).

The subject of the research carried out among representatives of dairy cooperatives from the Świętokrzyskie and Małopolskie provinces was an indication of the activities carried out by cooperatives from among those presented above, which, in their opinion, affect the value for customers on the following markets: home voivodship, other voivodships, the EU market and other main markets. They could indicate many answers. There was used purposeful selection of the sample. Direct interviews using a questionnaire survey were conducted among representatives of cooperatives representing $41 \%$ of the population, which resulted from the willingness to participate in the survey.

\section{Results}

The results of the carried out research on the identification of activities affecting the value for customers carried out by dairy cooperatives from the Świętokrzyskie and Małopolskie voivodships on individual markets in the area of sales marketing are presented in Table 1.

Table 1.

Activities affecting the value for customers carried out by dairy cooperatives from the Świętokrzyskie and Małopolskie provinces on individual markets in the area of sales marketing (in \%)

\begin{tabular}{|l|c|c|c|c|c|c|c|c|}
\hline \multirow{2}{*}{ Activity } & \multicolumn{2}{|c|}{$\begin{array}{c}\text { Home } \\
\text { voivodship* }\end{array}$} & \multicolumn{2}{c|}{$\begin{array}{c}\text { Other } \\
\text { voivodships* }\end{array}$} & \multicolumn{2}{c|}{$\begin{array}{c}\text { the EU } \\
\text { market* }\end{array}$} & \multicolumn{2}{c|}{$\begin{array}{c}\text { Other main } \\
\text { markets* }\end{array}$} \\
\cline { 2 - 10 } & $\dot{\mathbf{S}}$ & $\mathbf{M}$ & $\mathbf{S}$ & $\mathbf{M}$ & $\mathbf{S}$ & $\mathbf{M}$ & $\mathbf{S}$ & $\mathbf{M}$ \\
\hline Offering price-competitive products & 0 & 25 & 0 & 0 & 0 & 0 & 0 & 0 \\
\hline Application of promotional prices & 33 & 25 & 33 & 25 & 0 & 0 & 0 & 0 \\
\hline Targeting advertisement to end users & 0 & 0 & 67 & 0 & 0 & 0 & 0 & 0 \\
\hline Use of loyalty programs & 0 & 0 & 33 & 0 & 0 & 0 & 0 & 0 \\
\hline $\begin{array}{l}\text { The use of consumer promotion } \\
\text { (e.g. samples, coupons, contests, lotteries, } \\
\text { gifts, etc.) }\end{array}$ & 0 & 25 & 0 & 25 & 0 & 0 & 0 & 0 \\
\hline Use of public relations & & & & & & & & 0 \\
\hline Use of publicity & 33 & 0 & 0 & 0 & 0 & 0 & 0 & 0 \\
\hline $\begin{array}{l}\text { Wide sharing of information about the } \\
\text { offer }\end{array}$ & 67 & 0 & 33 & 0 & 0 & 0 & 0 & 0 \\
\hline
\end{tabular}


Cont. table 1.

\begin{tabular}{|l|c|c|c|c|c|c|c|c|}
\hline $\begin{array}{l}\text { Offering products with a competitive } \\
\text { warranty scope }\end{array}$ & 33 & 50 & 33 & 25 & 0 & 0 & 0 & 0 \\
\hline Individualizing the offer & 67 & 25 & 33 & 0 & 0 & 0 & 0 & 0 \\
\hline $\begin{array}{l}\text { Offering products on favorable terms of } \\
\text { payment / financing }\end{array}$ & 0 & 0 & 0 & 0 & 33 & 0 & 0 & 0 \\
\hline $\begin{array}{l}\text { Applying special conditions of sale } \\
\text { (discounts) }\end{array}$ & 33 & 0 & 33 & 0 & 0 & 0 & 0 & 0 \\
\hline $\begin{array}{l}\text { Offering products with a rich set of pre-, } \\
\text { around- and after-sales services }\end{array}$ & 0 & 50 & 0 & 25 & 0 & 0 & 0 & 0 \\
\hline $\begin{array}{l}\text { offering a competitive price for pre-, } \\
\text { around- and after-sales services }\end{array}$ & 33 & 25 & 0 & 0 & 0 & 0 & 0 & 0 \\
\hline
\end{tabular}

* Multiple responses.

Ś - Świętokrzyskie Voivodship, M - Małopolskie Voivodship

Source: own study based on the results of research and (Konieczna, 2016, p. 266).

When analyzing the table 1 it can be seen that:

- The activity of offering price-competitive products is not implemented by dairy cooperatives from the Świętokrzyskie Voivodship, and in the case of the Małopolskie Voivodship, it is implemented by $25 \%$ of cooperatives only in the territory of the home voivodship.

- The activity of applying promotional prices is carried out by $33 \%$ of dairy cooperatives from the Świętokrzyskie Voivodship and 25\% of cooperatives from the Małopolskie Voivodship in the mother voivodship and other voivodships territories. In other markets, this activity is not implemented.

- The activity of targeting advertisement to end users is not carried out by dairy cooperatives from the Małopolskie Voivodship on any market, and in the case of the Świętokrzyskie Voivodship, it is carried out by $67 \%$ of cooperatives only in other voivodships territory.

- The activity of applying loyalty programs is not carried out by dairy cooperatives from the Małopolska Voivodship on any market, and in the case of the Świętokrzyskie Voivodship, it is implemented by $33 \%$ of cooperatives only in other voivodships territory.

- The activity consisting in the application of consumer promotion (e.g. samples, coupons, contests, lotteries, gifts, etc.) is not carried out by dairy cooperatives from the Świętokrzyskie Voivodship, and in the case of the Małopolskie Voivodship, it is carried out by $25 \%$ of cooperatives only in the home voivodship and other voivodships territories.

- Activities involving the use of public relations and offering products on favorable terms of payment/financing are not implemented by the dairy cooperatives from Małopolskie Voivodship on any market, and in the case of Świętokrzyskie Voivodship are carried out by only $33 \%$ of cooperatives in the EU markets. 
- The activity consisting in the use of publicity is not carried out by dairy cooperatives from the Małopolska Voivodship on any market, and in the case of the Świętokrzyskie Voivodship, it is carried out by $33 \%$ of cooperatives only in the home voivodship market.

- The activity of wide sharing of information about the offer is not carried out by dairy cooperatives from the Małopolskie Voivodship, and in the case of the Świętokrzyskie Voivodship, it is implemented only by $67 \%$ of cooperatives on the home voivodship market and by $33 \%$ of cooperatives in other voivodships. In other markets, this activity is not implemented.

- The activity consisting in offering products with a competitive warranty scope is carried out by $33 \%$ of dairy cooperatives from the Świętokrzyskie Voivodship and $50 \%$ of cooperatives from the Małopolskie Voivodship in the home voivodship market, and is carried out by $33 \%$ of dairy cooperatives from the Świętokrzyskie Voivodship and $25 \%$ of cooperatives from the Małopolskie Voivodship in the territory of other voivodships. In other markets, this activity is not implemented.

- The activity of individualizing the offer is carried out by $67 \%$ of dairy cooperatives from the Świętokrzyskie Voivodship and 25\% of cooperatives from the Małopolskie Voivodship in the home voivodship market, and is carried out by $33 \%$ of dairy cooperatives from the Świętokrzyskie Voivodship in other voivodships territory. In other markets, this activity is not implemented.

- The activity of applying special conditions of sale (discounts) is not implemented by dairy cooperatives from the Małopolskie Voivodship, and in the case of the Świętokrzyskie Voivodship, it is implemented by $33 \%$ of the cooperatives only in the home voivodship and other voivodships markets.

- The activity of offering products with a rich set of pre-, around-sales and after-sales services is not carried out by dairy cooperatives from the Świętokrzyskie Voivodship, and in the case of the Małopolskie Voivodship, it is implemented only by $50 \%$ of cooperatives in the home voivodship and by $25 \%$ of cooperatives in other voivodships markets. In other markets, this activity is not implemented.

- The activity of offering a competitive price for pre-, around-sales and after-sales services is carried out by $33 \%$ of dairy cooperatives from the Świętokrzyskie Voivodship and 25\% of cooperatives from the Małopolskie Voivodship in the home voivodship market. In other markets, this activity is not implemented.

Table 1 also shows that:

- In the home voivodship market, cooperatives from both analyzed voivodships use promotional prices, offer products with a competitive warranty scope, individualize the offer, offer competitive prices for pre-, around-sales and after-sales services. In addition, cooperatives from the Świętokrzyskie Voivodship use publicity, special conditions of 
sale (discounts), and cooperatives from the Małopolska Voivodship use consumer promotion (e.g. samples, coupons, contests, lotteries, gifts, etc.) and offer pricecompetitive products and products with a rich set of services. pre-, around- and aftersales.

- On other voivodships markets, cooperatives from both voivodships apply promotional prices and offer products with a competitive warranty scope. In addition, cooperatives from the Świętokrzyskie Voivodship target advertising to end recipients, apply loyalty programs, widely share information about their offer, individualize the offer and apply special conditions of sale (discounts). On the other hand, cooperatives from the Małopolskie Voivodship use consumer promotion (e.g. samples, coupons, contests, lotteries, gifts, etc.) and offer competitively priced products and products with a rich set of pre-, around-sales and after-sales services.

- In the EU markets, only cooperatives from the Świętokrzyskie Voivodship use public relations and offer products on favorable terms of payment/financing. On the other hand, cooperatives from the Małopolskie Voivodship do not carry out any activities on this market.

- On other markets, no activities are carried out by cooperatives from both voivodships.

\section{Conclusions}

Taking into account the results of the research, it should be stated that, although activities related to sales marketing affect the value for the customer, most of them are not carried out by cooperatives. Moreover, among cooperatives that carry out any activities, two markets prevail, namely the area of the home voivodship and other voivodships, and in the case of other major markets, no action is implemented. In most cases, the voivodship in which the cooperatives operate differentiates the actions taken. Only in the case of applying promotional prices and offering products with a competitive scope of guarantees, activities are carried out in the home voivodship and other voivodships by cooperatives from both voivodships. In the territory of the mother voivodship, some cooperatives from the Świętokrzyskie and Małopolskie voivodships carry out 7 out of 14 activities related to sales marketing, with $71 \%$ of these activities differing between voivodships. In other voivodships markets, some cooperatives from the Świętokrzyskie Voivodship implement 7 out of 14 activities, while some cooperatives from the Małopolskie Voivodship implement only 2 out of 14 activities in the field of sales marketing, one of which is the same as in the case of dairy cooperatives from the Świętokrzyskie Voivodship. On the EU markets, only cooperatives from the Świętokrzyskie Voivodship carry out activities in this field, however, these are only 2 activities. 


\section{References}

1. Czubała, A. (ed.) (2012). Podstawy marketingu. Warszawa: PWE.

2. Domański, T. (1994). Księga marketingu. Praktyczny przewodnik dla menedżerów i przedsiębiorców. Kłudzienko: Centrum Kreowania Liderów.

3. Domański, T. (1998). Marketing dla menedżerów. Warszawa: PWN.

4. Durlik, I. (1995). Inżyneria Zarzadzania. Strategia $i$ Projektowanie Systemów Produkcyjnych. Warszawa: Placet.

5. Garbarski, L. (ed.) (2011). Marketing. Kluczowe pojęcia i praktyczne zastosowania. Warszawa: PWE.

6. Grzanka, I. (2009). Kapitat społeczny w relacjach z klientami, Warszawa: CeDeWu.pl.

7. Konieczna, I. (2015). Model biznesowy spółdzielni a model biznesowy przedsiębiorstw o innej formie organizacyjno-prawnej. Różnice, odrębność czynników sukcesu, Warszawa: Wydawnictwo Difin.

8. Konieczna, I. (2016). Działania rynkowe w obszarze marketingu sprzedaży jako źródło sukcesu przedsiębiorstwa na przykładzie spółdzielni mleczarskich z województwa świętokrzyskiego. In: H. Czubasiewicz, P. Grajewski, J. Waśniewski (eds.), Perspektywy spojrzenia na czynniki sukcesu organizacji XXI wieku (pp. 263-271). Gdańsk: Wydział Zarządzania Uniwersytetu Gdańskiego.

9. Ławicki, J.S. (2005). Marketing sukcesu - partnering. Warszawa: Difin.

10. Limański, A. (2007). Marketing w organizacjach non-profit. Warszawa: Difin.

11. Niestrój, R. (2002). Zarzq̨dzanie przedsiębiorstwem XXI wieku. Materiały konferencji naukowej Wydziały Zarzadzania. Kraków: Wydawnictwo Akademii Ekonomicznej.

12. Pieczykolan, R. (2005). Informacja marketingowa. Warszawa: PWE.

13. Sampson, E. (1996). Jak tworzyć własny wizerunek. Warszawa: Dom Wydawniczy ABC.

14. Stonehouse, G., Hamill, J., Campbell, D., Purdie, T. (2001). Globalizacja. Strategia i zarzadzanie. Warszawa: Wydawnictwo FELBERG SJA.

15. Żurawik, B. (1996). Zarządzanie marketingiem w przedsiębiorstwie. Warszawa: PWE. 